посібник для студентів вищих навчальних закладів. Слов'янськ : Вид-во Б. І. Маторіна, 2017. 233 с.

3. Петровська Т.В. Майстерність спортивного педагога: навч. посіб. К.: НУФВСУ, вид-во «Олімп. л-ра», 2015. 184 с.

4. Цьось А. В., Балахнічова Г. В., Заремба Л. В. Сучасні технології викладання спортивних дисциплін: навч. посібник. Луцьк : ВНУ ім. Лесі Українки, 2010. 132 с.

DOI https://doi.org/10.30525/978-9934-26-114-5-20

\title{
ПРОЦЕС «ВМОТИВОВАНОЇ СОЦІАЛІЗАЦЇ̈» УЧНІВ СЕРЕДНЬОГО ШКІЛЬНОГО ВІКУ В УМОВАХ ДИСТАНЦІЙНОГО НАВЧАННЯ
}

\author{
Ільницька Л. В. \\ докторант \\ Інститут проблем виховання НАПН Украӥни \\ м. Київ, Україна
}

Новітні виклики нашого часу, що пов'язані із сучасною епідемологічною ситуацією, яка суцільно видозмінює звичні процеси входження учнів у запланований ритм шкільного життя, виявляє найактуальніші акцентні «площини дистанційної взаємодії», як нетипової кореляції тієї соціалізації, яка належним чином дозволяє емоційно відкривати оточуюче різноманіття та безбар'єрно контактувати 3 однолітками, навчатися, а також невимушено переймати досвід при проявах поважного ставлення до наставників і вчителів та, що, в першу чергу, залишається важливим - органічно відкривати власну індивідуально-особистісну сутність у природному для шкільного віку середовищі знань.

Термінологічна складова «площини дистанційної взаємодії» укорінена у технологічний світ «мобільного темпоритму». Швидкісний інтернет зв'язок започаткував характерний темп обміну думками i враженнями, що стало популярним ще до часів пандемічних викликів спілкування на відстані за допомогою соціальних мереж відкрило інший знаково-символічний поступ здебільшого емоційної дієвості. Самовизначення в цих умовах - це легкість миттєвого потрапляння у середовище потрібної контактної групи. Готовність спілкуватися саме таким чином - це демонстрація вмотивованої «одномоментної 
комунікації». Разом з тим, розкриття власної думки при слушній нагоді та вдало сформульованої особистісної історії пролонгує поширення на доволі активну аудиторію власного напрямку особистісного самовизначення. В цьому плані, для шкільної аудиторії постає проблема винайдення орієнтирів у стихійності різнопланових пропозицій, інколи із врахуваннями існуючих перешкод, бо слід ще включити у передумови ризиків теперішньої комунікативної ситуації, здебільшого, і анонімну нав'язливість агресивно-емоційного поля наполегливого втручання у формування соціальних принципів ціннісного ставлення до пріоритетних інтересів та переваг юнацького віку. Тому, процес контролю над активною присутністю учнів у соціальних мережах, як поміркованого обмеження, полягає у перенаправленні учнівського інтересу у більш сконцетровану атмосферу вдало підібраних освітньо-ресурсних конгломератів 3 додатковим врахуванням функції розвантаження та дозвілля, які, в свою чергу, мають допомагати заповнити віртуальним чином порожнечу живого спілкування.

Слід передбачити, що віртуальний простір пропонує стихійну соціалізацію у вирі необмеженої комунікації і постає питання: як школярі не тільки сприймають світ у процесах пізнання, а також як вони намагаються сприймати дійсність, яка перенавантажена інформаційним змістом повсякчас оновленого ущільнення. Зрештою, в цьому плані процеси віртуального спілкування стають показником нетривких соціальних зв'язків, але $\epsilon$ і характерні тенденції. Попередньо зазначена одномоментна комунікація стає лакмусом швидкого спалаху захопливого ставлення до індивідуального повідомлення і такого ж швидкого знецінення не стільки інформаційного забарвлення, як самої індивідуальної суті, до якої випадково віртуально доторкнувшись, вже уможливлюється в подальшому, зновуж таки, втрата персонального інтересу. Тому, невибірково приєднані друзі у власний простір самопрезентації стають влучною домінантою входження суб'єктної лінії розповіді у соціально-комунікаційний процес перспективного зміцнення внутрішньої ціннісної структури. Наполегливе плекання відкривати розмаїття довколишнього світу для сучасної шкільної молоді взаємопов'язане із питанням відкритися світу своїх віртуальних друзів, наблизивши їх, ніби одномоментно існує потреба у подальшій підтримці одне одного, тоді і спілкування набуває іншої соціальної ваги. Відтак, вже налагоджений контакт у віртуальній мережі, по суті, стає містком дружби та емоційного взаємозбагачення, а безмежний вибір тем для спілкування дозволяе ще більше розширювати власну аудиторію та приєднуватися до вагомої для свого ціннісного поля та близької по соціальних зв'язках території одночасно спрямованої у 82 
потрібний кут, що важливо «цілеспрямованого споглядання» миттєво оновлюваних ресурсних пропозицій медійного джерела інформаційної системи.

Вочевидь, прояви особистісної стійкості перед магнетичними якостями невідомих відчуттів піднесеності та захопливих вражень додають неочікуваного ефекту від не стільки присутності, а скільки наявності невідомих людей, наміри яких так легко наслідувати, без врахування несподіваних дій такого типового впливу, популяризацією розкутих сполучень на поведінку підлітків. Статус незнайомої особи не обтяжує вразливість від віртуальної наявності товариського налаштування, коли, вже майже впізнавана людина 3 непевною конкретизацією персоніфікованого позиціонування у соціальних мережах, лише до якоїсь міри уточнює власні лінії самоідентифікації вмотивовує імпонувати їі реакціям на будь-який, що найголовніше, не віртуальний, а рельний життєвий світ в представлених подіях і фактах, підібраних на власний розсуд анонімної відповідальності. Таким чином, легка приваблюваність соціальних мереж - за швидке входження у соціально-комунікаційний простір - має зворотній бік рідкісного подразнення чуттєвої сфери людини будь-якої вікової групи. Втім, реальні загрози, які привносить віртуальна комунікація для відповідних, як для шкільної аудиторії, процесів соціалізації, ігнорувати вкрай важко. Також, до певної міри, слід залучити вмотивований погляд на вибірковість, як необхідний важіль внутрішньої перевірки при налаштуванні на виняткову відкриту присутність при спілкуванні, насамперед, 3 однолітками. Проте, вибірковість не усуває доброзичливого ставлення до, по-товариському налаштуванню, багаторічних однодумців у, майже власноруч, за рахунок цілеспрямованого споглядання, віртуально вибудованому комунікаційному світі - врештірешт, сприятливих контактів і пропозицій. Тобто, прояви повсякчасної гнучкості стають перевагами при довготривалій комунікації у соціальних мережах, але стриманість викликами анонімного до себе інтересу, здебільшого у вікової групи шкільної молоді, має 3 перевагами компенсуватися радісними обмінами враженнями від буденних подій, адже на відстані світ іншої людини споглядається через представлений до уваги калейдоскоп видовищних кадрів та повідомлень, які легко вподобати або проігнорувати, проявивши власний поступ до невипадкового комунікативного об'єднання зі світом приємної у спілкуванні людини.

На перший погляд, здається легким завданням віднайти потрібне комунікаційне середовище і викликати потрібний інтерес, але дружній простір стає лише таким, коли дитина навчається налагоджувати 
контакти на особистісному рівні - усвідомлено пропонувати власний контент подій, що дозволить в майбутньому згуртувати довколо себе людей ідентичного світоглядного взаємодоповнюючого погляду на реалістичне відчуття життя, як безкінечного ладу пропозицій та перспективних ідей.

Наразі, постає питання: як поступово навчити учнів тримати 3 однолітками зв'язок на відстані, адже в подальшому - це стане запорукою «вмотивованої соціалізації». Необхідні сполучники вдалої віртуальної комунікації уособлюють перенаправлення трансформаційних елементів вибудовування стосунків на відстані у коло взаємообміну враженнями, i це надає таким соціальним комунікаціям яскравого емоційного змісту, що і дозволяє пролонгувати здатність доєднуватися захопливим чином до інформаційного поля однокласників із власним комунікаційним наповненням.

Поміж іншим, така якість, як відповідальне ставлення до оточуючих, навіть серед віртуально незнайомих людей, за якими $\epsilon$ реальний душевний неспокій та інколи переживання, вмотивовує прискіпливіше ставитися до мовленнєвого формулювання. Отже, концентрація уваги при проведенні діалогів на відстані змушує по-іншому підходити до загальних принципів щодо вітальної самопрезентації. Як проявити на відстані посмішку не конкретно для когось, а для обраної плеяди дружніх онлайн поглядів? Це вагоме завдання для внутрішнього самоаналізу має усвідомлено пройти шкільна аудиторія із виявами щирої любові до оточуючих, як джерела внутрішнього відчуття подальшої перспективності від обраного комунікативного напрямку думки. Хоча і надлишок емоційної розкутості заважає усвідомлено сприймати серйозно віртуально обрану людину, але прийнятний намір самопозначення власної суб'єктності розфарбовує віддалену присутність живою емоцією відкритої натури з вмотивованим контекстом подальшого, хоча і знов віддаленого, спілкування. Такий активний поступ органічно демонструє, що процеси соціалізації на відстані існують і мають свій специфічний гатунок різноманітних якостей, над якими потрібно працювати повсякчас, готувати підростаюче покоління майбутніх активних користувачів соціальних мереж до оновленого темпоритму життя, де віртуальна реальність вмотивовує оцінювати наявні механізми соціалізації крізь призму необхідного досвіду одночасно рухливої та водночас доброзичливої соціальної мотивації входити до дистанційного режиму активного та приязного діалогу.

Важливо врахувати, що потрібно знайти вдало підібрані корелюючі позиції щодо формування певної соціально-комунікаційної програми по дистаційному налаштуванню учнівського середовища із 84 
додатковими пропозиціями по взаємообміну враженнями та думками 3 приводу не тільки шкільного життя, а й різнопланового об'єднання довколо найвигадливіших вікових зацікавлень - це, в подальшому, додасть учням впевненості, дозволить гнучко реагувати на нестандартні ситуації безмежного світу соціальних мереж і забезпечить вмотивоване ставлення до необхідного повсякчасного самоаналізу при ефективному проведенні комунікаційного режиму віртуального діалогу онлайн не тільки 3 однолітками, а й без винятку 3 різноманітними віковими групами населення. Таким чином, «вмотивована соціалізація» в сучасних умовах дистанційного навантаження допомагає осягнути весь комплекс виховних ускладнень та підкреслює навчальний наголос на тому, як потрібно тримати зацікавлений та доброзичливий зв'язок на відстані.

DOI https://doi.org/10.30525/978-9934-26-114-5-21

\title{
ОСОБЛИВОСТІ ОРГАНІЗАЦЇ̈ ВИХОВНОГО ПРОЦЕСУ КУРАТОРОМ АКАДЕМІЧНОЇ ГРУПИ ВИЩОГО НАВЧАЛЬНОГО ЗАКЛАДУ
}

\author{
Кривов'яз О. С. \\ здобувач $\mathrm{PhD}$, \\ асистент кафедри біологічної та медичної хімї \\ імені академіка Г. О. Бабенка \\ Івано-Франківський національний медичний університет \\ Нечитайло Л. Я. \\ кандидат біологічних наук, \\ асистент кафедри біологічної та медичної хімї \\ імені академіка Г. О. Бабенка \\ Івано-Франківський національний медичний університет \\ м. Івано-Франківськ, Украӥна
}

Процес соціалізації студента у вищому навчальному закладі здійснюється через навчання та виховання. Виховання виконує основну функцію, відповідаючи за цілеспрямоване формування особистості 3 метою підготовки іiі до активної участі в усіх різновидах життєдіяльності суспільства [1,с.152].

Виховна робота завжди $є$ невід'ємною частиною підготовки фахівців із вищою освітою, особливо коли мова йде про підготовку 